\title{
The ratio of Matriptase/HAl-I mRNA is higher in colorectal cancer adenomas and carcinomas than corresponding tissue from control individuals
}

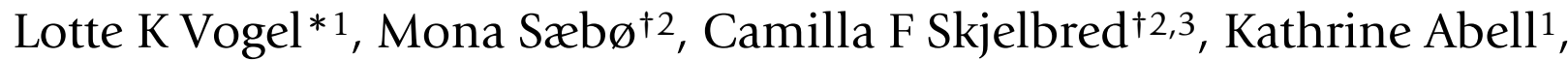 \\ Esben DK Pedersen ${ }^{1}$, Ulla Vogel ${ }^{4}$ and Elin H Kure ${ }^{2,5}$
}

\begin{abstract}
Address: ${ }^{1}$ Department of Medical Biochemistry and Genetics, University of Copenhagen, Blegdamsvej 3, Denmark, ${ }^{2}$ Telemark University College, Faculty of Arts and Sciences, Bø i Telemark, Norway, ${ }^{3}$ Department of Laboratory Medicine, Section of Medical Genetics, Telemark Hospital, Skien, Norway, ${ }^{4}$ National Institute of Occupational Health, Copenhagen, Denmark and ${ }^{5}$ Department of Pathology, Ullevaal University Hospital, Oslo, Norway

Email: Lotte K Vogel* - vogel@imbg.ku.dk; Mona Sæbø - mona.sabo@hit.no; Camilla F Skjelbred - camilla-furu.skjelbred@sthf.no; Kathrine Abell - abell@imbg.ku.dk; Esben DK Pedersen - ditlev@imbg.ku.dk; Ulla Vogel - ubv@ami.dk; Elin H Kure - elin.kure@baseline.no * Corresponding author †Equal contributors
\end{abstract}

Published: 04 July 2006

BMC Cancer 2006, 6:176 doi:10.1 186/147|-2407-6-176

This article is available from: http://www.biomedcentral.com/147I-2407/6/176

(C) 2006 Vogel et al; licensee BioMed Central Ltd.

This is an Open Access article distributed under the terms of the Creative Commons Attribution License (http://creativecommons.org/licenses/by/2.0), which permits unrestricted use, distribution, and reproduction in any medium, provided the original work is properly cited.

\begin{abstract}
Background: It has recently been shown that overexpression of the serine protease, matriptase, in transgenic mice causes a dramatically increased frequency of carcinoma formation. Overexpression of HAl-I and matriptase together changed the frequency of carcinoma formation to normal. This suggests that the ratio of matriptase to HAI-I influences the malignant progression. The aim of this study has been to determine the ratio of matriptase to HAl-I mRNA expression in affected and normal tissue from individuals with colorectal cancer adenomas and carcinomas as well as in healthy individuals, in order to determine at which stages a dysregulated ratio of matriptase/HAl-I mRNA is present during carcinogenesis.
\end{abstract}

Methods: Using quantitative RT-PCR, we have determined the mRNA levels for matriptase and HAI-I in colorectal cancer tissue $(n=9)$, severe dysplasia $(n=15)$, mild/moderate dysplasia $(n=21)$ and in normal tissue from the same individuals. In addition, corresponding tissue was examined from healthy volunteers $(\mathrm{n}=10)$. Matriptase and HAl-I mRNA levels were normalized to $\beta$ actin.

Results: Matriptase mRNA level was lower in carcinomas compared to normal tissue from healthy individuals $(p<0.0 \mathrm{I})$. In accordance with this, the matriptase mRNA level was also lower in adenomas/carcinomas combined as compared to their adjacent normal tissue $(\mathrm{p}<0.0 \mathrm{I})$. HAI-I mRNA levels in both normal and affected tissue from individuals with severe dysplasia or carcinomas and in affected tissue with mild/moderate dysplasia were all significantly lower than mRNA levels observed in corresponding tissue from healthy control individuals. HAI-I mRNA was lower in carcinomas as compared to normal tissue from healthy individuals $(p<0.00 \mathrm{I})$. HAl-I mRNA levels were significantly lower in tissue displaying mild/moderate $(p<0.00 \mathrm{I})$ and severe $(p<0.01)$ dysplasia compared to normal tissue from the same patients. Both adenomas and carcinomas displayed a significantly different matriptase/HAI-I mRNA ratio than corresponding normal tissue from healthy control individuals $(p<0.05)$. In addition statistically significant difference $(\mathrm{p}<0.00 \mathrm{I})$ could be observed between mild/moderate and severe adenomas and their adjacent normal tissue.

Conclusion: Our results show that dysregulation of the matriptase/HAI-I mRNA ratio occurs early during carcinogenesis. Future studies are required to clarify whether the dysregulated matriptase/HAI-I ratio was causing the malignant progression or is a consequence of the same. 


\section{Background}

Matriptase also known as MT-SP1, epithin, TADG-15 and SNC19, is the prototypic member of a recently identified matriptase subfamily of type II transmembrane serine proteases together with matriptase- 2 and matriptase-3 [17]. It has a multi-domain structure, including an aminoterminal cytoplasmic tail, a transmembrane region, a sperm protein, enterokinase, and agrin (SEA) domain, two complement subcomponents C1r/Cs, urchin embryonic growth factor and bone morphogenic protein (CUB) domain, four low density lipoprotein receptor class A repeats, and a carboxyl-terminal serine protease domain $[1,2,4,8]$. Matriptase is required for postnatal survival [9] and is essential for processing of pro-filaggrin which is important for epidermal differentiation [10]. Matriptase is co-expressed with its cognate inhibitor, hepatocyte growth factor activator inhibitor 1 (HAI-1) in many types of normal and malignant tissues of epithelial origin [1114]. HAI- 1 is a type 1 integral membrane, Kunitz-type serine protease inhibitor [15] and contains two Kunitz domains and a low density lipoprotein receptor class A domain. HAI-1 knock-out mice die during the embryonic development [16].

It has recently been shown that matriptase possesses a strong oncogenic potential since even a modest overexpression in the skin of transgenic mice caused $100 \%$ of the mice to develop tumors, $70 \%$ of which progressed into carcinomas [17]. Increased expression of HAI-1, completely negated the oncogenic effects of matriptase overexpression [17]. These data strongly suggest that a dysregulated ratio of matriptase to HAI-1 causes malignant transformation to occur at a high frequency whereas aberrant expression of matriptase or HAI-1 per se does not seem to be important.

Several studies suggest that matriptase is over-expressed in a wide variety of malignant tumors including prostate, ovarian, uterine, colon, epithelial-type mesothelioma and cervical cell carcinoma [4,12,18-22]. It has also been reported that HAI-1 is over-expressed in breast cancer [23]. However, none of these studies has focused on the ratio of matriptase/HAI-1 expression.

Prompted by the finding that a dysregulated ratio of matriptase to HAI-1 in mice results in tumor formation and carcinogenesis, we have analysed the ratio of matriptase/HAI-1 mRNA expression during colorectal cancer carcinogenesis in humans.

\section{Methods \\ Subject population}

The KAM cohort (Kolorektal cancer, Arv og Miljø) is based on the screening group of the Norwegian Colorectal Cancer Prevention study (The NORCCAP study) in the county of Telemark, Norway [24]. The ID number for the NORCCAP study at Clinicaltrials.gov is [I NCT00119912] [25]. A total of 20,780 men and women, age distribution 5064 years, drawn randomly from the population registries in Oslo (urban) and the county of Telemark (mixed urban and rural) were invited to have a flexible sigmoidoscopy screening examination with or without (1:1) an additional faecal occult blood test (FOBT). 777 individuals were excluded according to exclusion criteria [26]. The KAM biobank currently consists of 170 colorectal cancer cases, 991 cases with adenomas, and 400 controls. Controls were defined as individuals with normal findings at the flexible sigmoidoscopy screening. The colorectal cancer cases of the KAM biobank consist of patients operated on at Telemark Hospital and Ulleval University Hospital in Oslo. The KAM study is approved by the Regional Ethical Committee and the Norwegian Data Inspectorate. In the present study we have analyzed cases with carcinomas $(n=9)$, cases with adenomas $(n=36)$ and controls that were polyp free in the screened region of the colon $(\mathrm{n}=$ 10). From individuals with adenomas a sample of control tissue was collected $30 \mathrm{~cm}$ from anus. From patients with carcinomas, a sample of control tissue was taken from the surgically removed tissue, as far away from the tumor as possible. Control samples from healthy individuals were taken from individuals where no adenomas or carcinomas could be identified with flexible sigmoidoscopy. The histology of the adenomas was examined independently by two specialist histopathologists in order to determine the tumor stage as either mild/moderate $(n=21)$ or severe $(\mathrm{n}=15)$. They reached the same conclusion in all cases. The distribution of gender and age among cases with colonic carcinomas and adenomas and controls are shown in Table 1. One case with mild/moderate dysplasia showed no detectable mRNA for either $\beta$-actin, matriptase and HAI-1 and was therefore excluded from the study. Individuals with dysplasia, who developed carcinomas and were treated at the same hospital, were registered.

\section{RT-PCR}

Total RNA was purified from tissue as recommended by the manufacturers using Qiagen kit (AH diagnostics, Aarhus, Denmark). The tissue had been stored in liquid $\mathrm{N}_{2}$ before RNA purification. RNA purification included a DNAse treatment. The cDNA synthesis was performed on approximately $200 \mathrm{ng}$ RNA per $10 \mu \mathrm{l}$ using Gold RT-RCR kit (Applied Biosystems, Nærum, Denmark). Quantitative RT-PCR was performed on ABI7500 sequence detection system (Applied Biosystems) in Universal Mastermix (Applied Biosystems) using 160/140 nM probe and 600/ $300 \mathrm{nM}$ primers for matriptase and $H A I-1$, respectively. Matriptase: primers were matrip $\mathrm{F}$, 5'GCGCTCCCTGAAGTCCTTT3'; matrip R 5'GTCCTGGGTCCTCTGTACTGTTTT3'; probe, matrip $\mathrm{t}$ 5'FAM-TCACCTCAGTGGTGGCTTTCCCCA-BHQ-1-3'. 
Table I: Characteristics of cases and healthy persons used in this study

\begin{tabular}{|c|c|c|c|c|}
\hline & \multirow[t]{3}{*}{ Healthy } & \multicolumn{3}{|c|}{ Cases } \\
\hline & & \multicolumn{2}{|c|}{ Adenomas 1} & \multirow[t]{2}{*}{ Carcinoma } \\
\hline & & Mild/moderate Dysplasia & Severe dysplasia & \\
\hline & $(n=10)$ & $(n=20)$ & $(n=15)$ & $(n=9)$ \\
\hline Men $^{2}$ & 4 & 15 & 13 & 7 \\
\hline Women ${ }^{2}$ & 6 & 5 & 2 & 2 \\
\hline Mean age $+S D^{3}$ & $54.1 \pm 3.4$ & $59.1 \pm 3.1$ & $58.4 \pm 4.3$ & $61.67 \pm 9.1$ \\
\hline
\end{tabular}

IThe adenomas are divided in groups according to diagnosed degree of dysplasia (mild/moderate or severe).

2There were significantly more males in the group with severe dysplasia compared to the group of healthy individuals $(p=0.014)$. There was no significant difference in the number of males and females between the group of healthy individuals and the group with mild/medium dysplasia or between the group of healthy individuals and the group with carcinomas $\left(\chi^{2}\right.$ test).

${ }^{3}$ There are significant differences in age among the four groups of healthy and affected individuals at $95 \%$ confidence level. There is no significant difference in age between the three case groups (Mann-Whitney test).

HAI-1: primers were HAI 1 1532F 5'CGCGGCATCTCCAAGAAG3'; HAI 1 1651R 5'GAACACTGCGACAGCCATCTC3'; probe, HAI 1 1572T 5'FAM-AAATCCCCATTCCCAGCACAGGCTC-BHQ-1-3'. The HAI-1 primers detects both HAI-1 and the splice variant $H A I-1 B$. Primers were designed using Primer Express v2.0 Software. Primers were designed within different exons and with probes covering the exon-exon border to prevent amplification of genomic DNA. $18 S$ rRNA and $\beta$ actin primers and probes were obtained from Applied Biosystems. Matriptase and HAI-1 primers and probes were obtained from TAC Copenhagen. In a validation experiment using a control sample, a dilution series was produced and assayed for matriptase, HAI- 1 and $\beta$-actin as described for the comparative $C_{t}$ method [27]. When plotted it could be shown that the assays are quantitative over a range of 512-fold dilution for both matriptase and HAI1 and that the PCR reactions have similar efficiencies provided that a threshold of 0.2 is used for matriptase and $\beta$ actin while the threshold was 0.025 for HAI-1. The threshold is a fixed fluorescence signal level above the baseline. The $\mathrm{C}_{\mathrm{t}}$ value of a sample is determined as the fractional cycle number when the samples fluorescence signal exceeds the threshold. The threshold is thus assay specific, determined in the validation experiment and depends on the background of the individual assay. This implies that even though the amplification curves for matriptase and HAI-1 were overlapping, indicating that the two genes had the same relative abundance, the normalised HAI-1 mRNA level seemed higher due to the lower threshold used.

Matriptase, HAI-1, $\beta$-actin and $18 S$ were quantified separately in triplicates. The average standard deviation on triplicates was $6 \%$. The standard deviation on repeated measurements of the same sample (the control) in separate experiments was $8 \%$ and $14 \%$ for matriptase and $H A I$ -
1 respectively, indicating the day-to-day variation of the assay. Independent PCR reactions of the same samples yielded a correlation coefficient of 0.88 . Negative controls (where the RNA was not converted into cDNA) and positive controls were included in all sets. Essentially the same results were obtained whether the expression was normalised to $\beta$-actin or $18 S$ (correlation coefficient of 0.921 ).

\section{Statistical analysis}

MiniTab Statistical Software, Release 13.1 Xtra (Minitab Inc.) and GraphPad Prism 4 were used for the statistic calculations. The data were not adjusted for sex since the incidence ratio of colorectal cancer between the genders is 1.1 in Norway [28].

\section{Results}

The mRNA levels of matriptase and HAI-1 were measured in colon tissue samples from healthy control individuals $(\mathrm{n}=10)$ and in healthy and affected tissue from individuals with mild/moderate dysplasia $(n=21)$, with severe dysplasia $(n=15)$ and with colorectal cancer $(n=9)$ by real-time RT-PCR. We chose to normalise the mRNA levels of matriptase and HAI-1 to the mRNA level of $\beta$-actin. Essentially identical results were obtained when normalized to $18 S$ rRNA (see material and methods). We found that matriptase, HAI- 1 and $\beta$-actin mRNA's are present with almost the same abundances (Fig. 1 and Table 2) within one order of magnitude. This shows that the mRNA's of matriptase and HAI-1 are relative abundant.

The range and the interquartile range of mRNA expression of matriptase and HAI-1 normalised to $\beta$-actin are shown in Figure 1. The matriptase mRNA level tended to decrease with increasing tumor grade both in dysplastic and cancerous tissue as well as in normal tissue from the same individuals. When the matriptase mRNA level of healthy individuals was compared with colorectal cancer tissue, a 

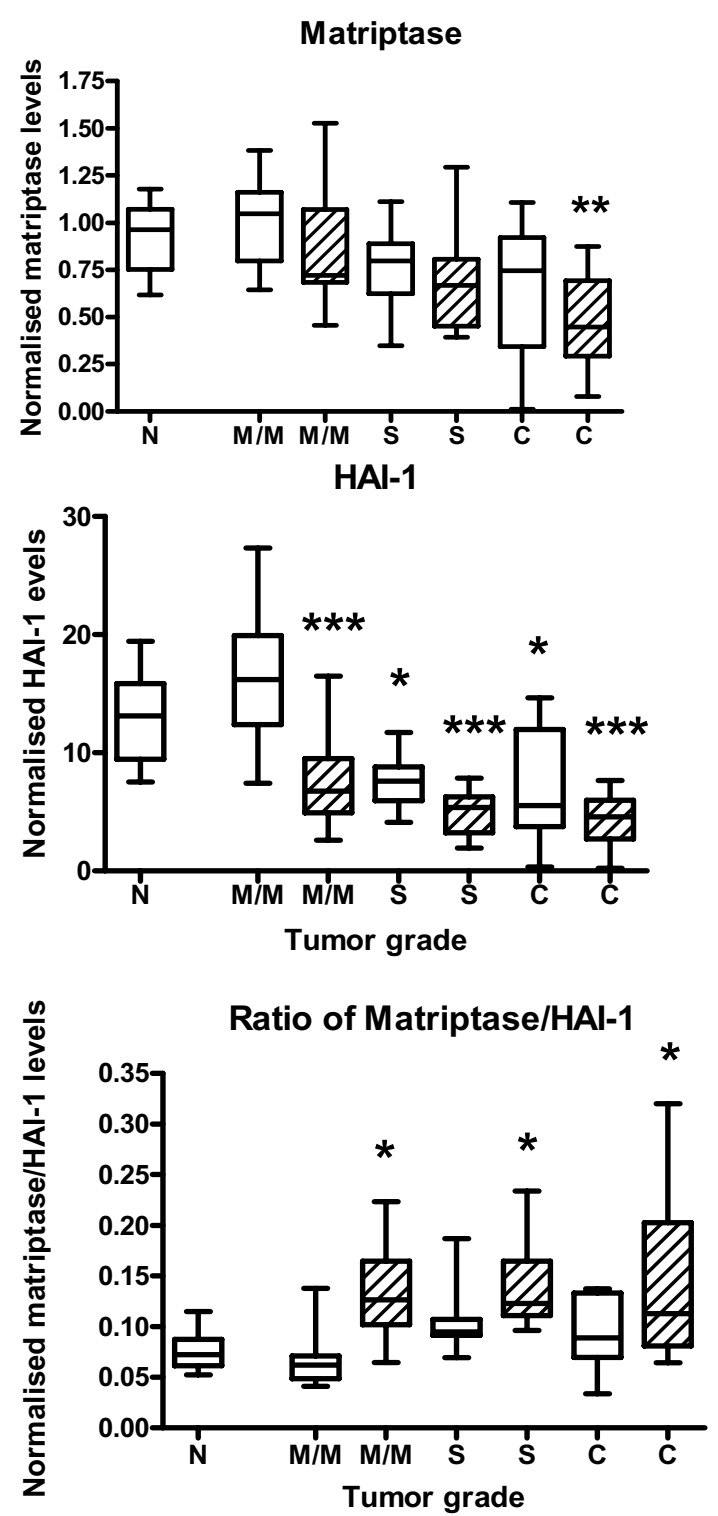

$$
\begin{array}{ll}
\text { Normal tissue } & { }^{*} \mathrm{p} \angle 0.05 \\
\boldsymbol{\square} \text { Tumor tissue } & { }^{* *} \mathrm{p} \angle 0.01 \\
& { }^{* * *} \mathrm{p} \angle 0.001
\end{array}
$$

\section{Figure I}

The mRNA expression of matriptase, HAl-I and the ratios between matriptase/HAI-I mRNAs determined by real-time RT-PCR from healthy individuals $(\mathbf{N})$, individuals with mild/moderate dysplasia (M/M), severe dysplasia (S) or carcinomas (C). Both normal (open bars) and affected (hatched bars) tissue were examined from each individual. Both mRNA levels were normalized to the $\beta$-actin mRNA level. The box shows the interquartile range, the whiskers the range and the median is indicated by a vertical line. statistically significant decrease ( $\mathrm{p}<0.01$ ) was observed (Table 2 and Fig. 1). Also the matriptase mRNA level of all adenomas and carcinomas combined were statistically significantly lower than the corresponding level in healthy tissue from the same individuals $(\mathrm{p}<0.01)$ (Table 2).

HAI-1 displayed a stronger general decrease in mRNA level with increasing tumor grade for both dysplastic and cancerous tissues as well as in normal tissue than matriptase (Fig. 1). A decrease of $65 \%$ was seen in carcinomas as compared to corresponding tissue in healthy control individuals. When comparing the expression level of $H A I-1$ in dysplastic and cancerous tissue with corresponding tissue from healthy individuals, statistically significant lower expression was encountered ( $\mathrm{p}<0.001)$ (Table 2 ) in all groups. There was also a statistically significant difference between normal tissue from healthy individuals and normal tissue from individuals with severe dysplasia and carcinomas ( $\mathrm{p}<0.05)$. When comparing affected tissue, with normal tissue from the same individual, we found a statistically significant difference for individuals with mild/moderate dysplasia $(\mathrm{p}<0.001)$ and severe dysplasia ( $\mathrm{p}<0.01)$. No statistically significant difference was seen in carcinoma tissue compared to unaffected tissue from the same person (Table 2). A comparison of all adenomas and carcinomas combined, with normal tissues from the same person also showed a statistically significant difference $(\mathrm{p}<0.001)$.

It has recently been shown that is was not the expression of matriptase per se but the ratio of matriptase/HAI-1 expression that determines the frequency of carcinoma formation in a mouse model [17]. We therefore investigated the ratio of matriptase/HAI-1 mRNA expression during colorectal carcinogenesis (Figure 1 and Table 2). We found a statistically significant higher ratio of matriptase/ HAI-1 mRNA levels in tissue with both mild/moderate dysplasia $(\mathrm{p}<0.05)$, severe dysplasia $(\mathrm{p}<0.05)$ and in carcinomas $(\mathrm{p}<0.05)$ when compared to corresponding tissue from healthy individuals. When compared to the ratio of matriptase/HAI-1 mRNA in normal tissue from the same individual there was a statistically significant difference for mild/moderate dysplasia ( $p<0.001)$, for severe dysplasia $(\mathrm{p}<0.001)$ and for all adenomas and carcinomas combined $(\mathrm{p}<0.001)$. No statistically significant difference was seen in carcinoma tissue compared to unaffected tissue from the same person (Table 2). Thus more unopposed matriptase is present in dysplastic and cancerous tissue than in corresponding tissue from healthy control individuals.

Four individuals with either mild/moderate and/or severe dysplasia later developed colorectal cancer during followup. The matriptase/HAI-1 mRNA levels in the tissue displaying dysplasia of these individuals are shown in Table 
Table 2: Matriptase and HAI-I mRNA levels in normal and affected tissues. The mRNA levels were normalised to $\beta$-actin mRNA levels.

\begin{tabular}{|c|c|c|c|c|c|}
\hline Variable & $\begin{array}{l}\text { mRNA level in normal } \\
\text { tissue Mean (SD) }\end{array}$ & $\mathrm{Pa}$ & $\begin{array}{c}\text { mRNA level in } \\
\text { adenomas/carcinomas } \\
\text { Mean (SD) }\end{array}$ & $\mathrm{Pa}$ & $\mathrm{Pb}$ \\
\hline \multicolumn{6}{|l|}{ Matriptase } \\
\hline Healthy people & $0.93(0.18)$ & & & & \\
\hline Mild/moderate & $1.02(0.23)$ & NS & $0.86(0.3 \mathrm{I})$ & NS & NS \\
\hline Severe & $0.74(0.22)$ & NS & $0.66(0.24)$ & NS & NS \\
\hline Carcinoma & $0.66(0.36)$ & NS & $0.49(0.25)$ & $<0.01$ & NS \\
\hline $\begin{array}{l}\text { All adenomas and } \\
\text { carcinomas }\end{array}$ & $0.85(0.29)$ & ND & $0.72(0.31)$ & ND & $<0.01$ \\
\hline \multicolumn{6}{|l|}{ HAI-I } \\
\hline Healthy people & $12.84(3.70)$ & & & & \\
\hline Mild/moderate & $16.35(5.22)$ & NS & $7.35(3.67)$ & $<0.001$ & $<0.001$ \\
\hline Severe & $7.55(2.12)$ & $<0.05$ & $4.93(1.83)$ & $<0.001$ & $<0.01$ \\
\hline Carcinoma & $7.17(4.79)$ & $<0.05$ & $4.26(2.25)$ & $<0.001$ & NS \\
\hline $\begin{array}{l}\text { All adenomas and } \\
\text { carcinomas }\end{array}$ & $11.47(6.23)$ & ND & $5.89(3.14)$ & ND & $<0.001$ \\
\hline \multicolumn{6}{|l|}{$\begin{array}{l}\text { Matriptase/HAI-I } \\
\text { ratio }\end{array}$} \\
\hline Healthy people & $0.076(0.018)$ & & & & \\
\hline Mild/moderate & $0.067(0.024)$ & NS & $0.132(0.044)$ & $<0.05$ & $<0.001$ \\
\hline Severe & 0.1020 .027 ) & NS & $0.142(0.044)$ & $<0.05$ & $<0.001$ \\
\hline Carcinoma & $0.095(0.036)$ & NS & $0.144(0.084)$ & $<0.05$ & NS \\
\hline $\begin{array}{l}\text { All adenomas and } \\
\text { carcinomas }\end{array}$ & $0.085(0.032)$ & ND & $0.138(0.053)$ & ND & $<0.001$ \\
\hline
\end{tabular}

NS = not significant, ND = not determined

a) $\mathrm{p}$ value for the comparison to the expression levels in healthy persons using a one-way ANOVA and Tukey's post test for paired comparisons.

b) $\mathrm{P}$ value for the comparison of the expression levels in normal and affected tissue from the same person using a paired T-test

3. These individuals did not have higher matriptase/HAI-1 ratios than the average in their group.

\section{Discussion}

In the present study we have determined the mRNA levels of matriptase and HAI-1 during colorectal cancer carcinogenesis. It has previously been shown that there is a good correlation between mRNA levels and protein levels for matriptase $[12,18,20]$ and HAI-1 [12].

It has previously been described that matriptase is up-regulated in various human carcinomas by factors of 5-600
$[4,12,14,18,19,22,29]$ and in prostatic tissue with a modest up-regulation [21]. This is in contrast to the present study where we observe a modest but significant $30 \%$ down-regulation of matriptase mRNA in carcinomas compared to corresponding tissue in healthy individuals. In a very recent study it was reported that matriptase mRNA is down-regulated in both gastric and colorectal cancer as compared to adjacent normal tissue [30]. This is in agreement with our observations as the matriptase mRNA level tended to decrease with increasing tumor grade.

Table 3: The matriptase/HAI-I ratio of individuals with mild/moderate or severe dysplasia who later developed carcinomas. The mRNA levels were normalised to $\beta$-actin mRNA levels.

\begin{tabular}{lcc}
\hline \multicolumn{2}{c}{ Matriptase/HAl-I ratio } \\
\hline KAM ID no. & Mild/moderate & Severe \\
\hline 278 & 0.124 & 0.100 \\
344 & & 0.115 \\
803 & 0.146 & 0.121 \\
193 & $0.132(0.044)$ & $0.142(0.044)$ \\
Mean (SD)* & & \\
\hline
\end{tabular}

*Mean (SD) of their group also listed in Table 2. 
Since it was recently shown that in mice it is not the matriptase expression per se, but the amount of HAI-1 unopposed matriptase that determined the frequency of malignant transformation [17] we also examined the expression of HAI-1 mRNA. We found a significant decrease of HAI-1 mRNA in tissue with mild/moderate dysplasia and in affected and normal tissue from individuals with severe dysplasia and carcinomas as compared to corresponding tissue from healthy control individuals. A HAI-1 down regulation has previously been described in renal cell carcinomas as compared to corresponding normal tissue from control individuals [31]. Recently it was also shown that HAI-1 mRNA level is down-regulated in gastric and colorectal cancer as compared to adjacent normal tissue [30]. This agrees well with our findings as also the HAI-1 mRNA level tended to decrease with increasing tumor grade.

When examining the ratio of matriptase to HAI-1 mRNA a significant altered ratio was found in affected tissue displaying mild/moderate dysplasia, severe dysplasia and in carcinomas as compared to corresponding tissue from control individuals. This means that more HAI-1 unopposed matriptase is present in in dysplastic and cancerous tissue, which in a mouse model has been shown to give a increased frequency of malignant transformation [17]. We did not observe any statistically significant differences between normal tissue from healthy individuals and unaffected tissue from individuals with adenomas or carcinomas, although HAI-1 mRNA level was statistically significantly lower in normal tissue from individuals with severe dysplasia and carcinomas compared to the level found in healthy persons. A larger number of cases should be studied in order to determine whether the matriptase/ HAI-1 ratio is dysregulated in unaffected tissue from individuals with severe dysplasia and carcinomas. In agreement with our study it was recently reported that the matriptase /HAI-1 mRNA ratio is not significantly different in colorectal cancer compared to adjacent normal tissue [30].

Collectively, this suggests that the dysregulated ratio between matriptase and HAI-1 can arise either by up regulation of the matriptase expression or by down regulation of the HAI-1 expression, or by a combination of the two depending on the type of cancer. Our data further suggest that the disturbance of the matriptase/HAI-1 ratio is an early event in colorectal cancer carcinogenesis as it is already present in tissue displaying mild/moderate dysplasia and that the dysregulation is maintained during all stages of malignant progression. It is interesting to note that even though both matriptase and HAI-1 is down regulated in colorectal cancer, a similar down regulation takes place in the adjacent normal tissue resulting in an unchanged matriptase/HAI-1 mRNA ratio.
It is at present unclear how a dysregulated matriptase/ HAI-1 ratio is connected to carcinogenesis as the biological function of matriptase is not well understood. It is known that matriptase is essential for processing of profilaggrin [10], but this is unlikely to be connected to its role during carcinogenesis. It is also known that matriptase can activate pro-urokinase, protease-activator receptor-2 and hepatocyte growth factor [8,32]. Whether this is important for the ability of unopposed matriptase to cause carcinomas is not clear [17].

The acquisition of the ability to invade surrounding tissue is a key event in carcinogenesis. Proteases are believed to play a crucial role in this process since dissolution of the extracellular matrix is a prerequisite for invasive growth and metastatic spread of tumor cells. Matriptase is possibly involved in this as the serine protease is expressed by the tumor cells themselves and CVS-3983, a matriptase inhibitor, has been developed and shown to retard tumor growth in a human prostate cancer xenograft model [33]. HAI-1 may play an importent role as it has been shown that HAI-1 at the invasive front of colorectal adenocarcinomas is most often in a mature, membrane-bound form, whereas ectodomain shedding is common in the rest of the tumor [34].

Interestingly, it was shown that even a modest dysregulated matriptase expression strongly potentiates chemical carcinogenesis in mice [17]. It was shown that matriptase induced spontaneous carcinoma formation that occurs independently of ras mutations, whereas carcinogeninduced tumors often are accompanied by H-ras or K-ras mutations. The dysregulated matriptase/HAI-1 ratio observed in mild/moderate and severe dysplasia may promote carcinogenesis by potentiating chemical carcinogenesis, and may thus be one of the underlying reasons why polyps transform into carcinomas.

Our results have shown that the abundance of the matriptase and HAI-1 mRNA are similar to each other and to that of $\beta$-actin within one order of magnitude. However, it has previously been shown that matriptase protein is present in very low levels in both normal and malignant epithelium (2-24 ng matriptase pr mg detergent-extractable protein) [12]. Likewise HAI-1 is not an abundant protein in mouse intestine (Vogel., L.K unpublished results). This may indicate that these proteins have a short half-life compared to $\beta$-actin or that the translation frequency of the mRNAs is low. Indeed the half life of HAI- 1 when recombinantly expressed in MDCK cells is in the range of a 1.5 hour (Godiksen, S. and Vogel, L.K., unpublished data). 


\section{Conclusion}

In conclusion, our study shows that dysregulation of the matriptase/HAI-1 mRNA ratio as compared to the corresponding tissue in healthy control individuals, is an early event in colorectal cancer carcinogenesis that is maintained during all stages of malignant progression. Future studies are required to clarify whether the dysregulated matriptase/HAI-1 ratio was causing the malignant progression or is a consequence of the same.

\section{Competing interests}

The author(s) declare that they have no competing interests.

\section{Authors' contributions}

LV and UV conceived the idea of the study. EHK designed the cohort and collected the samples. MS and CFS extracted the RNA, carried out the cDNA synthesis and performed most of the statistical calculations. UV and LV designed and validated primers and probes. LV carried out the RT-PCR and drafted the manuscript. KA and EDKP helped writing the manuscript. All authors helped interpret the results, writing the manuscript and read and approved the final version.

\section{Acknowledgements}

We thank Anne Karin Jensen for kind technical help and assistance.

This work was supported by The Norwegian Cancer Society (Grant numbers 5I024/00I and EOI-085 I00I), Telemark University College (Grant number 22069) and the Norwegian Colorectal Cancer Prevention (NORCCAP) study (Grants from the Norwegian Cancer Society and the Department of Health and Social Affairs) and with the aid of EXTRA funds from the Norwegian Foundation for Health and Rehabilitation (200 I/2/0 I I0), the Danish Medical Research Council (grant no 22-04-0467), Danish Research Council (grant no 2052-0300 16), The Illum Foundation, The Etatsråd Georg Bestle and Wife's Foundation, The Aase and Ejner Danielsens Foundation, the Danish Cancer Research Foundation, The Groser Sven Hansen and wife Ina Hansens Foundation

\section{References}

I. Kim MG, Chen C, Lyu MS, Cho EG, Park D, Kozak C, Schwartz RH: Cloning and chromosomal mapping of a gene isolated from thymic stromal cells encoding a new mouse type II membrane serine protease, epithin, containing four LDL receptor modules and two CUB domains. Immunogenetics 1999, 49:420-428.

2. Lin CY, Anders J, Johnson M, Sang QA, Dickson RB: Molecular cloning of cDNA for matriptase, a matrix-degrading serine protease with trypsin-like activity. J Biol Chem 1999, 274: $|823|-\mid 8236$.

3. Takeuchi T, Shuman MA, Craik CS: Reverse biochemistry: use of macromolecular protease inhibitors to dissect complex biological processes and identify a membrane-type serine protease in epithelial cancer and normal tissue. Proc Natl Acad Sci U S A 1999, 96: | |054-I 106I.

4. Tanimoto H, Underwood LJ, Wang YX, Shigemasa K, Parmley TH, O'Brien TJ: Ovarian tumor cells express a transmembrane serine protease: A potential candidate for early diagnosis and therapeutic intervention. Tumor Biology 200I, 22:104-I I4.

5. Velasco G, Cal S, Quesada V, Sanchez LM, Lopez-Otin C: Matriptase-2, a membrane-bound mosaic serine proteinase predominantly expressed in human liver and showing degrading activity against extracellular matrix proteins. J Biol Chem 2002, 277:37637-37646.

6. Hooper JD, Campagnolo L, Goodarzi G, Truong TN, Stuhlmann H, Quigley JP: Mouse matriptase-2: identification, characterization and comparative mRNA expression analysis with mouse hepsin in adult and embryonic tissues. Biochem J 2003, 373:689-702.

7. Szabo R, Netzel-Arnett S, Hobson JP, Antalis TM, Bugge TH: Matriptase-3 is a novel, evolutionarily conserved matriptasel MT-SPI homologue that encodes a functional type II transmembrane serine protease with conserved expression in mice and humans. Thrombosis and Haemostasis 2005, 93:AI7-AI7.

8. Takeuchi T, Harris JL, Huang W, Yan KW, Coughlin SR, Craik CS: Cellular localization of membrane-type serine protease I and identification of protease-activated receptor- 2 and single-chain urokinase-type plasminogen activator as substrates. J Biol Chem 2000, 275:26333-26342.

9. List K, Haudenschild CC, Szabo R, Chen W, Wahl SM, Swaim W, Engelholm LH, Behrendt N, Bugge TH: Matriptase/MT-SPI is required for postnatal survival, epidermal barrier function, hair follicle development, and thymic homeostasis. Oncogene 2002, 21 :3765-3779.

10. List K, Szabo R, Wertz PW, Segre J, Haudenschild CC, Kim SY, Bugge $\mathrm{TH}$ : Loss of proteolytically processed filaggrin caused by epidermal deletion of Matriptase/MT-SPI. J Cell Biol 2003, 163:901-910.

II. Benaud C, Oberst M, Hobson JP, Spiegel S, Dickson RB, Lin CY: Sphingosine I-phosphate, present in serum-derived lipoproteins, activates matriptase. J Biol Chem 2002, 277:I 0539- 10546.

12. Oberst M, Anders J, Xie B, Singh B, Ossandon M, Johnson M, Dickson RB, Lin CY: Matriptase and HAI-I are expressed by normal and malignant epithelial cells in vitro and in vivo. Am J Pathol 200I, I58:|30I-|3|I.

13. Oberst MD, Johnson MD, Dickson RB, Lin CY, Singh B, Stewart M, Williams A, al Nafussi A, Smyth JF, Gabra H, Sellar GC: Expression of the serine protease matriptase and its inhibitor HAI-I in epithelial ovarian cancer: correlation with clinical outcome and tumor clinicopathological parameters. Clin Cancer Res 2002, 8: II0I-II07.

14. Kang JY, Dolled-Filhart M, Ocal IT, Singh B, Lin CY, Dickson RB, Rimm $\mathrm{DL}$, Camp RL: Tissue microarray analysis of hepatocyte growth factor/Met pathway components reveals a role for Met, matriptase, and hepatocyte growth factor activator inhibitor $I$ in the progression of node-negative breast cancer. Cancer Res 2003, 63: I101-1105.

15. Shimomura T, Denda K, Kitamura A, Kawaguchi T, Kito M, Kondo J, Kagaya S, Qin L, Takata H, Miyazawa K, Kitamura N: Hepatocyte growth factor activator inhibitor, a novel Kunitz-type serine protease inhibitor. J Biol Chem 1997, 272:6370-6376.

16. Tanaka H, Nagaike K, Takeda N, Itoh H, Kohama K, Fukushima T, Miyata S, Uchiyama S, Uchinokura S, Shimomura T, Miyazawa K, Kitamura N, Yamada G, Kataoka H: Hepatocyte growth factor activator inhibitor type I (HAl-I) is required for branching morphogenesis in the chorioallantoic placenta. Molecular and Cellular Biology 2005, 25:5687-5698.

17. List K, Szabo R, Molinolo A, Sriuranpong V, Redeye V, Murdock T, Burke B, Nielsen BS, Gutkind SJ, Bugge TH: Deregulated matriptase causes ras-independent multistage carcinogenesis and promotes ras-mediated malignant transformation. Genes \& Development 2005, 19:1934-1950.

18. Hoang CD, D'Cunha J, Kratzke MG, Casmey CE, Frizelle SP, Maddaus MA, Kratzke RA: Gene expression profiling identifies matriptase overexpression in malignant mesothelioma. Chest 2004, I 25: 1843-1852.

19. Santin AD, Zhan FH, Bellone S, Palmieri M, Cane S, Bignotti E, Anfossi S, Gokden M, Dunn D, Roman JJ, O'Brien TJ, Tian EM, Cannon MJ, Shaughnessy J, Pecorelli S: Gene expression profiles in primary ovarian serous papillary tumors and normal ovarian epithelium: Identification of candidate molecular markers for ovarian cancer diagnosis and therapy. International Journal of Cancer 2004, I I 2:14-25.

20. Santin AD, Cane' S, Bellone S, Bignotti E, Palmieri M, Las Casas LE, Anfossi S, Roman JJ, O'Brien T, Pecorelli S: The novel serine protease tumor-associated differentially expressed gene- 15 (matriptase/MT-SPI) is highly overexpressed in cervical carcinoma. Cancer 2003, 98:1898-1904. 
21. Riddick ACP, Shukla CJ, Pennington CJ, Bass R, Nuttall RK, Hogan A, Sethia KK, Ellis V, Collins AT, Maitland NJ, Ball RY, Edwards DR: Identification of degradome components associated with prostate cancer progression by expression analysis of human prostatic tissues. British Journal of Cancer 2005, 92:2 I II-2 I 80.

22. Lee JW, Yong SS, Choi JJ, Lee SJ, Kim BG, Park CS, Lee JH, Lin CY, Dickson RB, Bae DS: Increased expression of matriptase is associated with histopathologic grades of cervical neoplasia. Hum Pathol 2005, 36:626-633.

23. Parr C, Watkins G, Mansel RE, Jiang WG: The hepatocyte growth factor regulatory factors in human breast cancer. Clin Cancer Res 2004, 10:202-2।I.

24. Gondal G, Grotmol T, Hofstad B, Bretthauer M, Eide TJ, Hoff G: The Norwegian Colorectal Cancer Prevention (NORCCAP) screening study. Scandinavian Journal of Gastroenterology 2003 , 38:635-642.

25. [http: W, www.clinicaltrials.gov/]: . 2006.

26. Gondal G, Grotmol T, Hofstad B, Bretthauer M, Eide T], Hoff G: The Norwegian Colorectal Cancer Prevention (NORCCAP) screening study: baseline findings and implementations for clinical work-up in age groups $\mathbf{5 0 - 6 4}$ years. Scand J Gastroenterol 2003, 38:635-642.

27. Johnson MR, Wang KS, Smith JB, Heslin MJ, Diasio RB: Quantitation of dihydropyrimidine dehydrogenase expression by realtime reverse transcription polymerase chain reaction. Analyt ical Biochemistry 2000, 278: 175-184.

28. Norway TCR: Cancer in Norway 200I Oslo, InfoPrint as; 2004.

29. Johnson MD, Oberst MD, Lin CY, Dickson RB: Possible role of matriptase in the diagnosis of ovarian cancer. Expert Rev Mol Diagn 2003, 3:33I-338.

30. Zeng L, Cao J, Zhang X: Expression of serine protease SNCI9/ matriptase and its inhibitor hepatocyte growth factor activator inhibitor type $I$ in normal and malignant tissues of gastrointestinal tract. World Journal of Gastroenterology 2005, I I:6202-6207.

31. Yamauchi M, Kataoka H, Itoh H, Seguchi T, Hasui Y, Osada Y: Hepatocyte growth factor activator inhibitor types $I$ and 2 are expressed by tubular epithelium in kidney and downregulated in renal cell carcinoma. Journal of Urology 2004, | 7 |:890-896.

32. Lee SL, Dickson RB, Lin CY: Activation of hepatocyte growth factor and urokinase/plasminogen activator by matriptase, an epithelial membrane serine protease. Journal of Biological Chemistry 2000, 275:36720-36725.

33. Galkin AV, Mullen L, Fox WD, Brown J, Duncan D, Moreno O, Madison EL, Agus DB: CVS-3983, a selective matriptase inhibitor, suppresses the growth of androgen independent prostate tumor xenografts. Prostate 2004, 61 :228-235.

34. Nagaike K, Kohama K, Uchiyama S, Tanaka H, Chijiiwa K, Itoh H, Kataoka $\mathrm{H}$ : Paradoxically enhanced immunoreactivity of hepatocyte growth factor activator inhibitor type I (HAI-I) in cancer cells at the invasion front. Cancer Science 2004, 95:728-735.

\section{Pre-publication history}

The pre-publication history for this paper can be accessed here:

http://www.biomedcentral.com/1471-2407/6/176/pre pub
Publish with Biomed Central and every scientist can read your work free of charge

"BioMed Central will be the most significant development for disseminating the results of biomedical research in our lifetime. "

Sir Paul Nurse, Cancer Research UK

Your research papers will be:

- available free of charge to the entire biomedical community

- peer reviewed and published immediately upon acceptance

- cited in PubMed and archived on PubMed Central

- yours - you keep the copyright

Submit your manuscript here:

http://www.biomedcentral.com/info/publishing_adv.asp
BioMedcentral 